Article

\title{
Simple Synthesis of $\mathrm{K}_{4} \mathrm{Nb}_{6} \mathrm{O}_{17} / \mathrm{C}$ Nanosheets for High-Power Lithium-Ion Batteries with Good Stability
}

\author{
Xiangwei Wang, Yunyun Zhai, Chunxia Kuang, Haiqing Liu *(D) and Lei Li * \\ College of Biological, Chemical Sciences and Engineering, Jiaxing University, Jiaxing 314001, China; \\ wangxiangwei@mail.zjxu.edu.cn (X.W.); zhaiyunyun@mail.zjxu.edu.cn (Y.Z.); kuangcx@mail.zjxu.edu.cn (C.K.) \\ * Correspondence: liuhaiqing@mail.zjxu.edu.cn (H.L.); lei.li@mail.zjxu.edu.cn (L.L.)
}

Received: 18 November 2018; Accepted: 7 January 2019; Published: 15 January 2019

\begin{abstract}
In this work, a series of two-dimensional (2D) large-size nanosheets were prepared through one-step exfoliation of the huge $\mathrm{K}_{4} \mathrm{Nb}_{6} \mathrm{O}_{17}$ crystals. The $\mathrm{K}_{4} \mathrm{Nb}_{6} \mathrm{O}_{17}$ nanosheets with the thickness of about $2 \mathrm{~nm}$ was used as the templates of dopamine polymerization and was then carbonized to form C-doped $\mathrm{K}_{4} \mathrm{Nb}_{6} \mathrm{O}_{17}$ nanosheets. More importantly, the C-doped $\mathrm{K}_{4} \mathrm{Nb}_{6} \mathrm{O}_{17}$ nanosheets exhibited excellent electrochemical performance with high specific capacity $\left(381 \mathrm{~mA} \mathrm{~h} \mathrm{~g} \mathrm{~g}^{-1}\right.$ at $0.05 \mathrm{~A} \mathrm{~g}^{-1}$, $0.5-3.0 \mathrm{~V}$ vs. $\mathrm{Li} / \mathrm{Li}^{+}$) and stable cyclability at high current density (remarkably, preserved a capacity of discharge approximately $90 \mathrm{~mA} \mathrm{~h} \mathrm{~g}^{-1}$ at $5 \mathrm{~A} \mathrm{~g}^{-1}$ after 1000 cycles). The good electrochemical performances of the C-doped $\mathrm{K}_{4} \mathrm{Nb}_{6} \mathrm{O}_{17}$ nanosheets can be attributed to the outstanding 2D structure and large specific surface, which afforded the short transport route for ion and electron. These noteworthy results demonstrated that the new 2D nanomaterials might be potential candidates for the high-performance, environmentally friendly, and low-cost electrochemical energy storage equipment.
\end{abstract}

Keywords: potassium niobate nanosheets; polydopamine; high rate performance; lithium-ion batteries

\section{Introduction}

Advanced energy storage techniques [1,2] have drawn widespread attention since the need for matching the new electricity production technologies, such as solar, tidal, wind, etc [3]. Lithium-ion batteries (LIBs) have become a topic of international research due to their long cycling lifetime, high working voltage, high energy density, high rate capability, and environment-friendliness $[4,5]$. It could be an important complement for the insufficient of the other power sources, for instance, supercapacitors and fuel cells [6-8]. However, commercial graphite is hard to adapt to the demand of widely application duo to the slow $\mathrm{Li}^{+}$diffusion rate and the formation of solid electrolyte interface (SEI) [9]. To solve the above-mentioned problem of commercial graphite anode, different electrode materials, for instance, multifarious carbon materials [10], mixed metal oxides [11], conducting polymers [12], et al. have been widely used as LIBs electrode materials. Unfortunately, the ion and electron transport paths of these materials are too long to achieve the desired results. Therefore, it is highly necessary to fabricate the novel electrode materials with high transmission efficiency.

The extensive research of graphene has evoked the attention to other two-dimensional (2D) materials. Particularly, metal oxide nanosheets are fascinating due to their wide variety of composition and structure. It is worth highlighting that niobium oxide, including $\mathrm{NbO}, \mathrm{NbO}_{2}, \mathrm{Nb}_{2} \mathrm{O}_{3}, \mathrm{Nb}_{2} \mathrm{O}_{5}$, and $\mathrm{Nb}_{3} \mathrm{O}_{7} \mathrm{X}(\mathrm{X}=\mathrm{OH}, \mathrm{F})$, have exhibited superior performance in many fields, such as catalysis, sensors, supercapacitors, solar cells, and LIBs [13-15]. T- $\mathrm{Nb}_{2} \mathrm{O}_{5}$ /graphene composite papers showed a superior pseudocapacitor performance as free-standing electrodes and excellent rate capability [16]. A 
three-dimensional holey-graphene/niobia $\left(\mathrm{Nb}_{2} \mathrm{O}_{5}\right)$ composite had an ultrahigh-rate energy storage at practical levels of mass loading ( $>10 \mathrm{mg} \mathrm{cm}^{-2}$ ) [17].

Among them, $\mathrm{K}_{4} \mathrm{Nb}_{6} \mathrm{O}_{17}$ has an ion-exchangeable layered structure, which own two kinds of alternating interlayer spaces (interlayers I and II), where $\mathrm{K}^{+}$ions are located. The interlayers are hydrated in aqueous solution [18]. The cation-rich layered structure facilitates ion and electron transport, thus enhancing the transfer efficiency greatly. Altrathin $\mathrm{SnNb}_{2} \mathrm{O}_{6}$ nanosheets has been reported by a simple hydrothermal route with $\mathrm{K}_{4} \mathrm{Nb}_{6} \mathrm{O}_{17}$ nanosheets as the precursor [19]. Qinglin Deng [20] reported a hydrothermal reaction to acquire layered $\mathrm{K}_{4} \mathrm{Nb}_{6} \mathrm{O}_{17}$ anode material, which manifested a largish initial discharge specific capacity of approximately $513 \mathrm{~mA} \mathrm{~h} \mathrm{~g}^{-1}$ at $0.2 \mathrm{~A} \mathrm{~g}^{-1}$. However, as the number of cycle time increases, the capacity declines rapidly to $84 \mathrm{~mA} \mathrm{~h} \mathrm{~g}^{-1}$ because of the SEI film formation and structural collapse. Until now, few details about the application of $\mathrm{K}_{4} \mathrm{Nb}_{6} \mathrm{O}_{17}$ in LIBs were provided in previous research. To the best of our knowledge, how to improve the capacity of $\mathrm{K}_{4} \mathrm{Nb}_{6} \mathrm{O}_{17}$ at high current density has not been previously discussed.

In this work, we synthesized a range of $2 \mathrm{D}$ large-size $\mathrm{K}_{4} \mathrm{Nb}_{6} \mathrm{O}_{17}$ ultrathin-nanosheet, followed via the polymerization of carbon-rich dopamine precursor and ultimate carbonization of the $\mathrm{K}_{4} \mathrm{Nb}_{6} \mathrm{O}_{17}$-polydopamine composites. Due to the doped carbon, the conductivity of the $\mathrm{K}_{4} \mathrm{Nb}_{6} \mathrm{O}_{17} / \mathrm{C}$ nanosheets were improved, and thus enhanced the cyclability and rate capability. The cell based $\mathrm{K}_{4} \mathrm{Nb}_{6} \mathrm{O}_{17}-\mathrm{C}-800$ nanosheets exhibited high initial capacity $\left(381 \mathrm{~mA} \mathrm{~h} \mathrm{~g}^{-1}\right.$ at $0.05 \mathrm{~A} \mathrm{~g}^{-1}$, with the voltage range of $0.5-3.0 \mathrm{~V}$ vs. $\left.\mathrm{Li} / \mathrm{Li}^{+}\right)$. Moreover, the cell based $\mathrm{K}_{4} \mathrm{Nb}_{6} \mathrm{O}_{17}-\mathrm{C}-800$ anode also possessed excellent rate performance (133 and $67 \mathrm{~mA} \mathrm{~h} \mathrm{~g}^{-1}$ at 1 and $5 \mathrm{~A} \mathrm{~g}^{-1}$, respectively) and stable cyclability (demonstrated a discharge capacity of approximately $150 \mathrm{~mA} \mathrm{~h} \mathrm{~g}^{-1}$ after 200 cycles, equivalent to approximately $84 \%$ of the 20th cycle at $0.1 \mathrm{~A} \mathrm{~g}^{-1}$ ), which were superior to the previously reported niobium oxide composites.

\section{Materials and Methods}

\subsection{Materials}

$\mathrm{Nb}_{2} \mathrm{O}_{5}, \mathrm{~K}_{2} \mathrm{CO}_{3}, n$-Propylamine, dopamine (DA), $\mathrm{N}$-methyl-2-pyrrolidone (NMP), poly-vinylidene fluoride (PVDF), and conductive carbon black were purchased from Sigma-Aldrich. A liquid electrolyte consisting of $1 \mathrm{M} \mathrm{LiPF}_{6}$ in ethylene carbonate/dimethyl carbonate/ethyl methyl carbonate (1/1/1, weight ratio) with the addition of $1 \mathrm{wt} \%$ vinylene varbonate was provided by Shenzhen Kejingstar Technology Ltd. (Shenzhen, China). Deionized water was used in all experiments, and all of the chemicals were used without being further purified.

\subsection{Sample Preparation}

The $\mathrm{K}_{4} \mathrm{Nb}_{6} \mathrm{O}_{17}$ single crystal was synthesized based on the flux method [21]. In a typical exfoliation process [22], $\mathrm{K}_{4} \mathrm{Nb}_{6} \mathrm{O}_{17}$ crystal $(0.30 \mathrm{~g})$, water $(60 \mathrm{~mL})$, and $n$-Propylamine (3.0 mL) was added into a Teflon-lined vessel and maintained at $120{ }^{\circ} \mathrm{C}$ for $3 \mathrm{~d}$. The $\mathrm{K}_{4} \mathrm{Nb}_{6} \mathrm{O}_{17}$ ultrathin-sheets slurry obtained by low-speed centrifugation.

$\mathrm{K}_{4} \mathrm{Nb}_{6} \mathrm{O}_{17}$ ultrathin-sheet slurry $(2 \mathrm{~mL})$ was dissolved in deionized water $(120 \mathrm{~mL})$. Subsequently, a calculated amount of DA (the mass ratio of $\mathrm{K}_{4} \mathrm{Nb}_{6} \mathrm{O}_{17}$ and DA is 1:1) was dropped under stirring. After $1 \mathrm{~h}, \mathrm{NH}_{4} \mathrm{OH}(0.3 \mathrm{~mL}, 28 \mathrm{wt} \%)$ was injected into the mixture and stirred for two days for the polymerization. The product was named as $\mathrm{K}_{4} \mathrm{Nb}_{6} \mathrm{O}_{17}-\mathrm{PDA}$. It was rinsed with distilled water for at least three times. The composites were calcined in a horizontal resistance furnace under $\mathrm{Ar}$ at $800{ }^{\circ} \mathrm{C}$ for $2 \mathrm{~h}$ to obtain $\mathrm{K}_{4} \mathrm{Nb}_{6} \mathrm{O}_{17}-\mathrm{C}-800$. With the same method, the $\mathrm{K}_{4} \mathrm{Nb}_{6} \mathrm{O}_{17}-\mathrm{PDA}$ was calcined at 400, 600, 700 , 900, and $1000{ }^{\circ} \mathrm{C}$, which were denoted as $\mathrm{K}_{4} \mathrm{Nb}_{6} \mathrm{O}_{17}-\mathrm{C}-400, \mathrm{~K}_{4} \mathrm{Nb}_{6} \mathrm{O}_{17}-\mathrm{C}-600, \mathrm{~K}_{4} \mathrm{Nb}_{6} \mathrm{O}_{17}-\mathrm{C}-700$ $\mathrm{K}_{4} \mathrm{Nb}_{6} \mathrm{O}_{17}-\mathrm{C}-900$, and $\mathrm{K}_{4} \mathrm{Nb}_{6} \mathrm{O}_{17}-\mathrm{C}-1000$, respectively. For comparison, the $\mathrm{K}_{4} \mathrm{Nb}_{6} \mathrm{O}_{17}$ nanosheets were also annealed at $800{ }^{\circ} \mathrm{C}$ for $2 \mathrm{~h}$ and named as $\mathrm{K}_{4} \mathrm{Nb}_{6} \mathrm{O}_{17}-800$. 


\subsection{Characterization}

The scanning electron microscopy (SEM, Hitachi S-4800, Tokyo, Japan) was used to measure the microstructure of all samples. The high-resolution transmission electron microscopy (HRTEM) was performed on a JEM-2100F (Tokyo, Japan). The phases of as-obtained samples were identified via $X$-ray diffractometer (XRD, DX-2600, Dandong, China) using $\mathrm{Cu} K \alpha$ radiation $(\lambda=0.15406 \mathrm{~nm})$. Raman measurement was performed on an Invia-Reflrx Laser Micro-Raman spectrometer (Renishaw, London, England). The thickness of the $\mathrm{K}_{4} \mathrm{Nb}_{6} \mathrm{O}_{17}$ nanosheets was obtained via atomic force microscopy (AFM) images (Multimode Nanoscope IIIa, Tokyo, Japan).

\subsection{Electrochemical Tests}

To examine electrochemical properties of the respective samples, CR-2016 type cells (Kejingstar Technology Ltd, Shenzhen, China) were assembled with Li metal as the counter and reference electrodes simultaneously, and Celgard 2320 (Kejingstar Technology Ltd, Shenzhen, China) as the separator in a glovebox. A liquid electrolyte consisting of 1M LiPF6 in ethylene carbonate/dimethyl carbonate/ethyl methyl carbonate $(1 / 1 / 1, w / w / w)$ with the addition of $1 \mathrm{wt} \%$ vinylene carbonate was provided by Shenzhen Kejingstar Technology Ltd. (Shenzhen, China). The working electrodes were prepared by blending the electroactive materials $(70 \mathrm{wt} \%)$, conductive carbon black (20 $\mathrm{wt} \%)$, and PVDF $(10 \mathrm{wt} \%)$ in NMP. After that, the ultimate slurry was spread on the $\mathrm{Cu}$ foil and desiccated in vacuum at $60{ }^{\circ} \mathrm{C}$ for $24 \mathrm{~h}$. In addition, the desiccated electrodes were roll-pressed. The cyclic voltammetry (CV) tests were measured at $0.1-1 \mathrm{mV} \mathrm{s}^{-1}$ within a range of $0.5-3.0 \mathrm{~V}$ using an electrochemical workstation (CHI 760E, CH Instruments Ins, Shanghai, China). The impedance test was carried out by an AC impedance analyzer (IM 6ex, Zahner, Kronach, Germany) with a frequency range of $1 \mathrm{M} \mathrm{Hz}-0.1 \mathrm{~Hz}$. The as-made coin cells were cycled at $0.05-5 \mathrm{~A} \mathrm{~g} \mathrm{~g}^{-1}$ using the Land CT2001A battery cycler (LAND, Wuhan, China) with the voltage range of $0.5-3.0 \mathrm{~V}$.

\section{Results}

The preparation route was schematically described in Scheme 1 . The synthesis of $\mathrm{K}_{4} \mathrm{Nb}_{6} \mathrm{O}_{17}-\mathrm{C}$ nanosheet consisted of exfoliated $\mathrm{K}_{4} \mathrm{Nb}_{6} \mathrm{O}_{17}$, the polymerization of the dopamine (DA), and carbonization. Firstly, the two-layer $\mathrm{K}_{4} \mathrm{Nb}_{6} \mathrm{O}_{17}$ ultrathin-sheets were acquired by a template-free and one-step synthesis. As we can see in Figure 1a, the sharp peaks at $9.5^{\circ}$ and $22.2^{\circ}$ are indexed to the (040) and (151) crystalline facets of $\mathrm{K}_{4} \mathrm{Nb}_{6} \mathrm{O}_{17}$ crystal, indicating that the degree of crystallization is high, and the spatial arrangement of the microchip layer is unconventional. After stripping by propylamine, the peaks that are located at $9.5^{\circ}$ and $22.2^{\circ}$ shift to $8.3^{\circ}$ and $21.2^{\circ}$, respectively, and the diffraction peaks become broader and weaker. It is indicated that the layer of potassium citrate has been stripped by the insertion of propylamine molecules, and thus decreasing the crystal structure integrity and increasing the degree of disorder. The inset shows a big $\mathrm{K}_{4} \mathrm{Nb}_{6} \mathrm{O}_{17}$ crystal $(2 \mathrm{~mm})$ and the SEM of $\mathrm{K}_{4} \mathrm{Nb}_{6} \mathrm{O}_{17}$ crystal before exfoliated, there is an obvious thicker layered structure, which provides the possibility for further exfoliation to obtain the nanosheets. A few micron-sized debris during the treatment process also can be exfoliated. From Figure 1b, we can find that the zeta potential was between $-20 \mathrm{mV}$ to $-58 \mathrm{mV}$ at the $\mathrm{pH}$ from 2 to 12 . It was very effective for the homogeneous adsorption and polymerization of DA on the surface of $\mathrm{K}_{4} \mathrm{Nb}_{6} \mathrm{O}_{17}$ nanosheets because of their negative charge $(\mathrm{pH}=10$, zeta potential $=47 \mathrm{mV})$. The inset of Figure $1 \mathrm{~b}$ was $\mathrm{K}_{4} \mathrm{Nb}_{6} \mathrm{O}_{17}$ nanosheet dispersion. The dispersion was very stable after two weeks because of the electrostatic repulsion from abundant negative charges. 

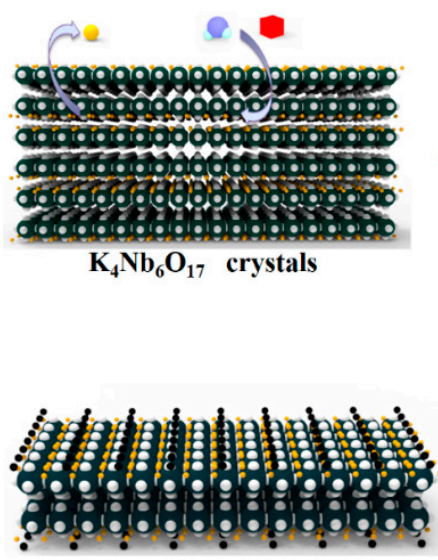

$\mathrm{K}_{4} \mathrm{Nb}_{6} \mathrm{O}_{17}-\mathrm{C}-800$

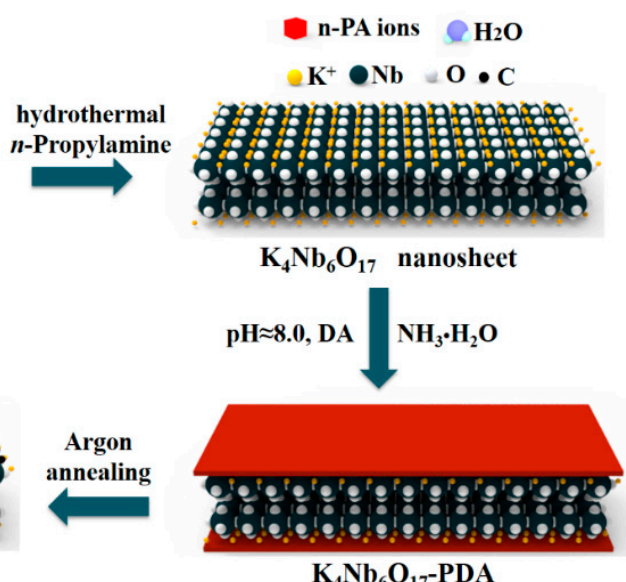

$\mathrm{K}_{4} \mathrm{Nb}_{6} \mathrm{O}_{17}-\mathrm{PDA}$

Scheme 1. A schematic route for preparation of the $\mathrm{K}_{4} \mathrm{Nb}_{6} \mathrm{O}_{17}-\mathrm{C}-800$.
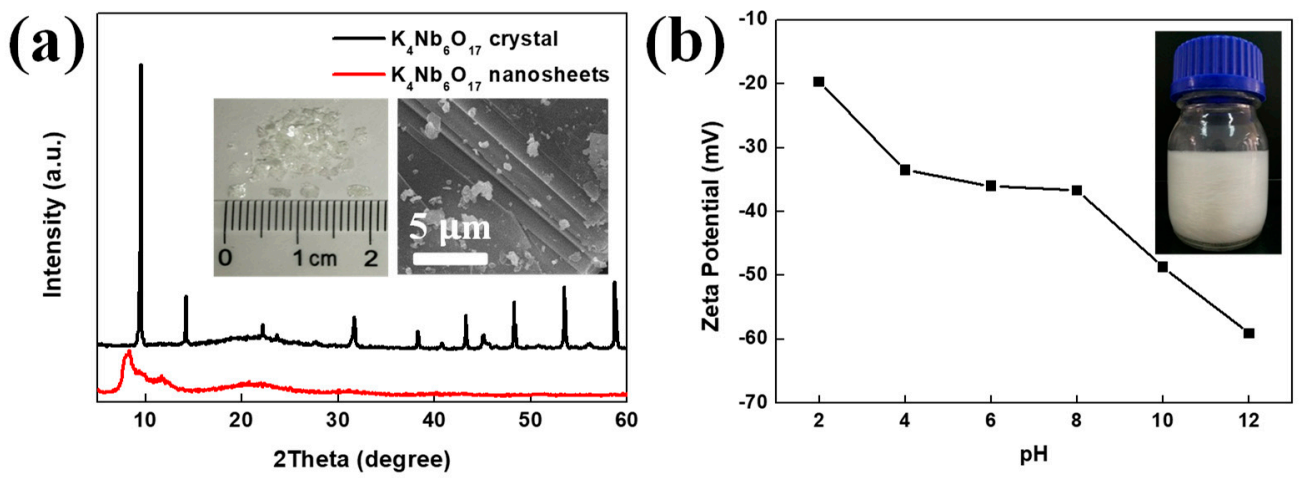

Figure 1. (a) X-ray diffractometer (XRD) spectra of $\mathrm{K}_{4} \mathrm{Nb}_{6} \mathrm{O}_{17}$ crystal and $\mathrm{K}_{4} \mathrm{Nb}_{6} \mathrm{O}_{17}$ nanosheets. Inset was the optical photograph (left) and SEM image (right) of $\mathrm{K}_{4} \mathrm{Nb}_{6} \mathrm{O}_{17}$ crystal. (b) Zeta potential of $\mathrm{K}_{4} \mathrm{Nb}_{6} \mathrm{O}_{17}$ nanosheets dispersion. Inset was the single to few-layer dispersion in water $\left(60 \mathrm{mg} \mathrm{mL}^{-1}\right)$.

From Figure 2a, we can conclude ultrathin $\mathrm{K}_{4} \mathrm{Nb}_{6} \mathrm{O}_{17}$ nanosheets with lateral dimension that is about a dozen even several dozen microns can be observed, showing a typical 2D morphology. As indicated by the AFM image in Figure $2 b$, the thickness of as-prepared $\mathrm{K}_{4} \mathrm{Nb}_{6} \mathrm{O}_{17}-\mathrm{C}$ nanosheet was approximately $2 \mathrm{~nm}$. Meanwhile, TEM characterization in Figure 2c,d further confirmed the characteristic of ultrathin thickness, which was beneficial for the transport of the ion and electron.

As we can see in Figure $3 \mathrm{a}-\mathrm{c}$, with the increase of calcination temperature, the thickness of $\mathrm{K}_{4} \mathrm{Nb}_{6} \mathrm{O}_{17}-\mathrm{C}$ slightly increased due to the formation of doped carbon and the overlay of slice layer in the thermal process. Whereas, the thickness had obviously turned to dozens of nanometers when the thermal temperature was higher than $800{ }^{\circ} \mathrm{C}$ (Figure 3d-e). From Figure 3f, we can find there was amorphous carbon onto the surface of crystallographic $\mathrm{K}_{4} \mathrm{Nb}_{6} \mathrm{O}_{17}$ nanosheets. The numbers of active bits and specific surface areas increased greatly due to the carbon coating, which will effectively improve the electrochemical performance. In Figure $4 \mathrm{a}$, the two peaks at 1353 and $1598 \mathrm{~cm}^{-1}$ can be attributed to D- and G-bands of carbon, respectively. It is obvious that the pure $\mathrm{K}_{4} \mathrm{Nb}_{6} \mathrm{O}_{17}$ nanosheets do not have D- and G-bands. After carbonization, the intensity is converted from strong D-band to strong G-band as the carbonization temperature increases, which indicates that the degree of disorder decreases and the number of nanosheets increases with the carbonization temperature increase. The disorder degree decreases and recrystallization effect is obvious, the results correspond to XRD. It is reinforced that the evidence that the carbon with $2 \mathrm{D}$ architecture was converted from PDA after carbonization. The XRD diffraction patterns that are shown in Figure $4 \mathrm{~b}$ illustrated that the crystals agree well with that of $\mathrm{K}_{4} \mathrm{Nb}_{6} \mathrm{O}_{17}$ of the JCPDS data file 21-1297. Also, the crystallinity of $\mathrm{K}_{4} \mathrm{Nb}_{6} \mathrm{O}_{17}$ was gradually increased with the increase of calcination temperature. However, after carbonizing 
at $400{ }^{\circ} \mathrm{C}$ and $600{ }^{\circ} \mathrm{C}$, it was obvious that the PDA was coated on the surface and was incomplete carbonized, the uncarbonized PDA hindered the electron conduction. After carbonizing at $900{ }^{\circ} \mathrm{C}$ and $1000{ }^{\circ} \mathrm{C}$, the nanosheets overlapped and the crystallinity was too high, which leads to the increase of diffusion channel of lithium ions and reduces the $\mathrm{Li}^{+}$embedding and desorption efficiency during the charge-discharge process. After carbonizing at $800^{\circ} \mathrm{C}$, the PDA layer carbonized completely and the thickness of the $\mathrm{K}_{4} \mathrm{Nb}_{6} \mathrm{O}_{17}-\mathrm{C}$ nanosheet did not increase, which was beneficial for $\mathrm{Li}^{+}$/ electron transport and the maintenance of the nanosheets structure. Moreover, HRTEM in Figure $3 \mathrm{f}$ shows that the crystallinity of $\mathrm{K}_{4} \mathrm{Nb}_{6} \mathrm{O}_{17}$ ultrathin-sheets was very high, which agreed with the XRD results. The coated amorphous carbon and flake structure increase the active bits of $\mathrm{Li}^{+}$/electron transport, and thus improving the cyclability and rate capability.
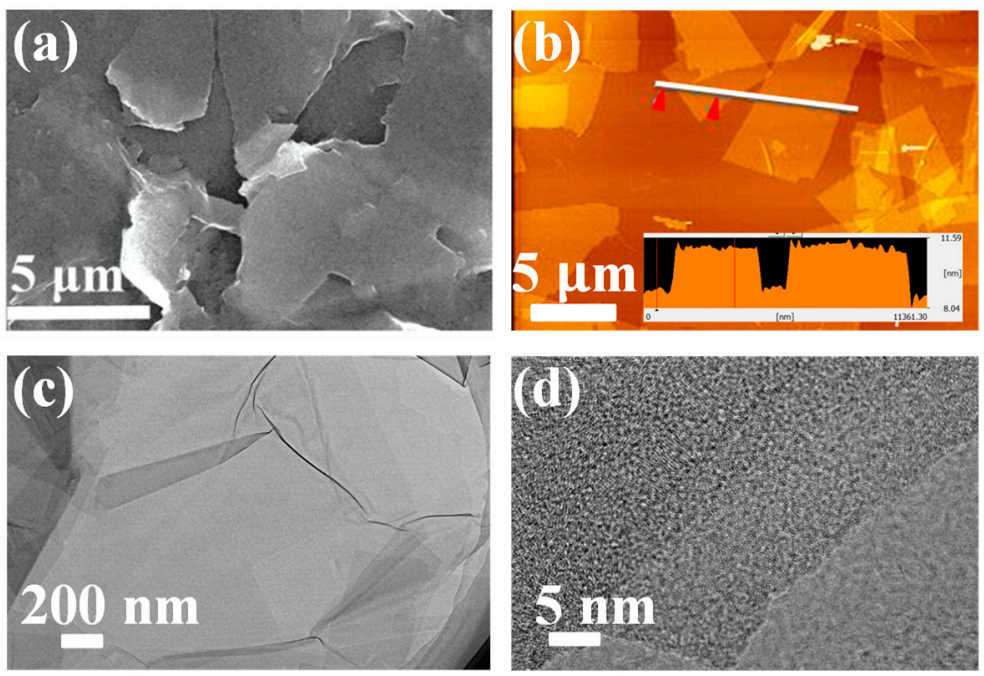

Figure 2. (a) Scanning electron microscopy (SEM), (b) atomic force microscopy (AFM), and (c,d) TEM images of $\mathrm{K}_{4} \mathrm{Nb}_{6} \mathrm{O}_{17}$ nanosheets.
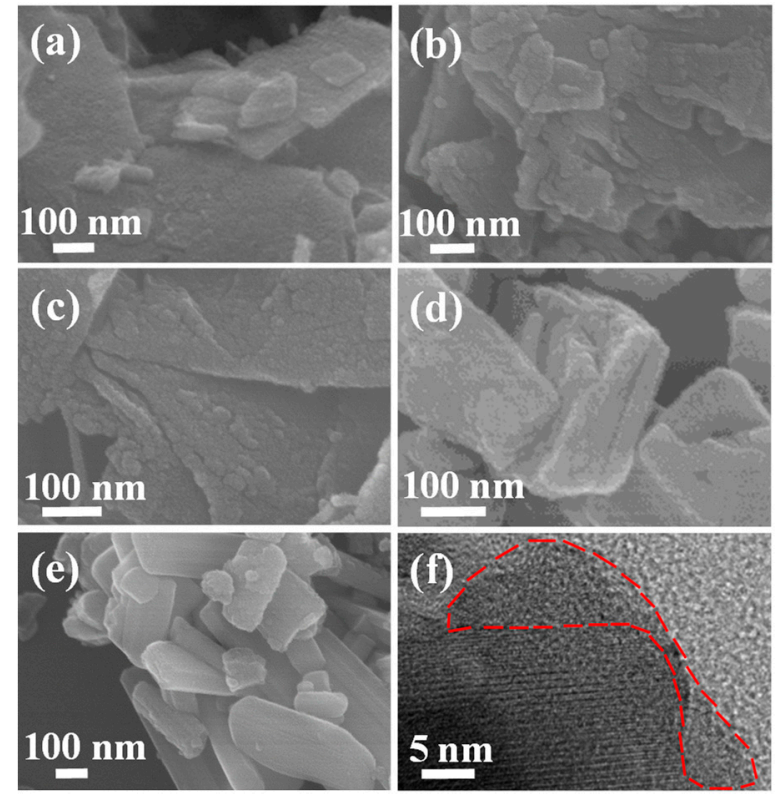

Figure 3. SEM images of $\mathrm{K}_{4} \mathrm{Nb}_{6} \mathrm{O}_{17}-\mathrm{C}-400$ (a), $\mathrm{K}_{4} \mathrm{Nb}_{6} \mathrm{O}_{17}-\mathrm{C}-600$ (b), $\mathrm{K}_{4} \mathrm{Nb}_{6} \mathrm{O}_{17}-\mathrm{C}-800$ (c), $\mathrm{K}_{4} \mathrm{Nb}_{6} \mathrm{O}_{17}-\mathrm{C}-900$ (d), $\mathrm{K}_{4} \mathrm{Nb}_{6} \mathrm{O}_{17}-\mathrm{C}-1000$ (e). (f) TEM image of $\mathrm{K}_{4} \mathrm{Nb}_{6} \mathrm{O}_{17}-\mathrm{C}-800$. 

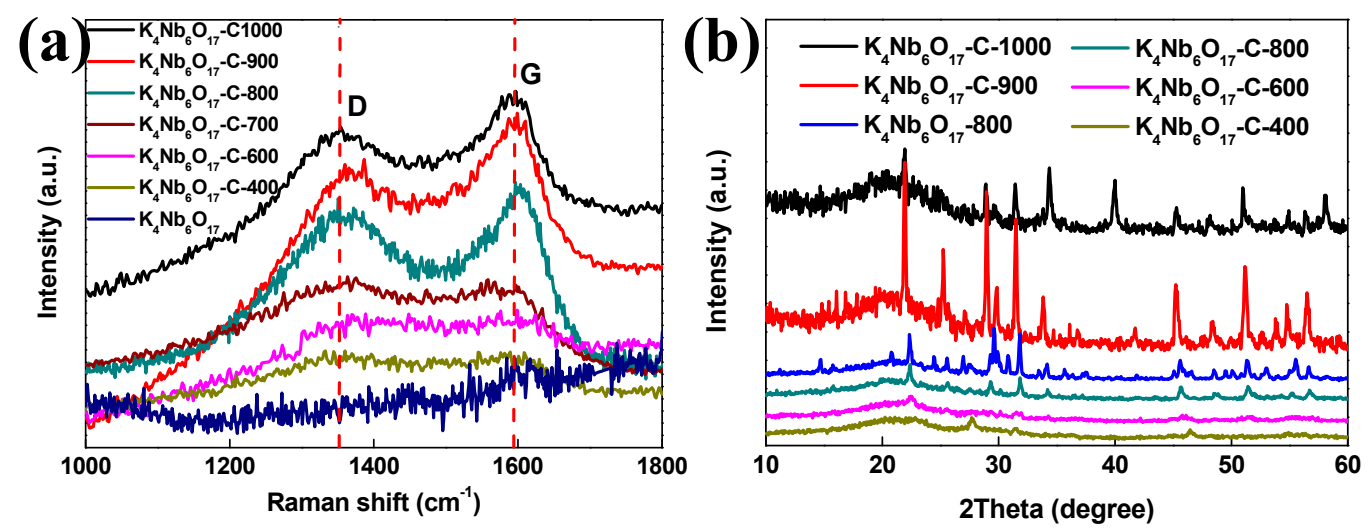

Figure 4. (a) Raman spectra of $\mathrm{K}_{4} \mathrm{Nb}_{6} \mathrm{O}_{17}-\mathrm{C}-800$. (b) $\mathrm{XRD}$ patterns of $\mathrm{K}_{4} \mathrm{Nb}_{6} \mathrm{O}_{17}-\mathrm{C}$.

To investigate the electrochemical performances of lithium ions insertion/extraction, as-prepared $\mathrm{K}_{4} \mathrm{Nb}_{6} \mathrm{O}_{17}-\mathrm{C}-800$ was measured using representative $\mathrm{CV}$ curves for the initial three cycles in the range of $0.5-3.0 \mathrm{~V}$ at $0.5 \mathrm{mV} \mathrm{s}^{-1}$. As we can see in Figure $5 \mathrm{a}$, the oxidation peaks at about 1.00 and $1.75 \mathrm{~V}$ vs. $\mathrm{Li}^{+} / \mathrm{Li}$ were observed when the first oxidation process $\left(\mathrm{Li}^{+}\right.$extraction) and the reduction peak at approximately $1.21 \mathrm{~V}$ vs. $\mathrm{Li}^{+} / \mathrm{Li}$ was shown in the first reduction process $\left(\mathrm{Li}^{+}\right.$insertion). The following CV curves demonstrated quite good repeatability. As shown in Figure 5b, CV measurements at scan rates of 0.1 to $1 \mathrm{mV} \mathrm{s}^{-1}$ were used to explore the electrochemical characteristics of $\mathrm{K}_{4} \mathrm{Nb}_{6} \mathrm{O}_{17}-\mathrm{C}-800$ electrode. There are a series of redox broad peaks, indicating that the $\mathrm{Li}^{+}$insertion/extraction into/from $\mathrm{K}_{4} \mathrm{Nb}_{6} \mathrm{O}_{17}-\mathrm{C}-800$ is a highly reversible process. The current peaks of cathodic and anodic shift noteworthily with the increase in scan speed, which may be attributed to the ohmic contributions of diffusion control process. The capacity of $\mathrm{K}_{4} \mathrm{Nb}_{6} \mathrm{O}_{17}-\mathrm{C}-800$ is calculated via integrating the discharge process of $\mathrm{CV}$, especially, the specific capacitance of $\mathrm{K}_{4} \mathrm{Nb}_{6} \mathrm{O}_{17}-\mathrm{C}-800$ was $102 \mathrm{~mA} \mathrm{~h} \mathrm{~g}{ }^{-1}$ at $1 \mathrm{mV}$ $\mathrm{s}^{-1}$ (Figure 5c), showing a high-rate storage capability, which can be attributed to the high ionic conductivity and amorphous carbon coated layer structure of $\mathrm{K}_{4} \mathrm{Nb}_{6} \mathrm{O}_{17}-\mathrm{C}-800$ nanosheets. Due to the special behavior of $\mathrm{K}_{4} \mathrm{Nb}_{6} \mathrm{O}_{17}-\mathrm{C}-800$ nanosheets, the currents are in direct accordance with the scan rates in the CV tests, obeying the power law $[23,24]\left(i=k v^{b}\right.$, where $k$ and $b$ both variable coefficients, $i$ and $v$ are current $(\mathrm{A})$, and scan rate $\left(\mathrm{mV} \mathrm{s}^{-1}\right)$, respectively). The parameter $b$ varies between 0.5 and 1 , and the values of 0.5 and 1 are represented the diffusion-limited process (charge by $\mathrm{Li}^{+}$insertion, battery-style) and the capacitive process (charge by surface capacitive effects, supercapacitor-style), respectively. As we can see in Figure 5d, the $b$ value was 1 for the current peaks of cathodic and anodic at $0.1-1 \mathrm{mV} \mathrm{s}^{-1}$, manifesting a fast $\mathrm{Li}^{+}$insertion process with a representative capacitive behavior. To differentiate quantitatively the effect of capacitance to the current response via the scan rate [25], we can use the formula, as follows:

$$
\begin{gathered}
i=k_{1} v+k_{2} v^{0.5} \\
i / v^{0.5}=k_{1} v+k_{2}
\end{gathered}
$$

where $k_{1}$ and $k_{2}$ are both befitting values. The surface capacitive process manifests fast kinetics and can be represented as $k_{1} v(b=1)$, while the diffusion-controlled process is represented as $k_{2} v^{0.5}(b=0.5)$. By plotting $v^{0.5}$ versus $i / v^{0.5}, k_{1}$ and $k_{2}$ were determined from the slope and the Y-intercept. Based on this, the capacitive mechanisms with $0.1 \mathrm{mV} \mathrm{s}^{-1}$ contributed approximately $64 \%$ of the total capacity for $\mathrm{K}_{4} \mathrm{Nb}_{6} \mathrm{O}_{17}-\mathrm{C}-800$ (Figure $5 \mathrm{e}$ ). As shown in Figure $5 \mathrm{f}$, the charge of surface effects increased sharply with the increase of sweep rate, from $64 \%$ at $0.1 \mathrm{mV} \mathrm{s}^{-1}\left(153 \mathrm{~mA} \mathrm{~h} \mathrm{~g}^{-1}\right)$ to $95 \%$ at $1 \mathrm{mV} \mathrm{s}^{-1}\left(102 \mathrm{~mA} \mathrm{~h} \mathrm{~g}^{-1}\right)$. This clearly indicated that the carbon doping increased the electron transport pathways, improving the electron transport property of the as-prepared $\mathrm{K}_{4} \mathrm{Nb}_{6} \mathrm{O}_{17}-\mathrm{C}-800$ nanosheets, which was beneficial for the enhancement of the rate capability and cyclability. 

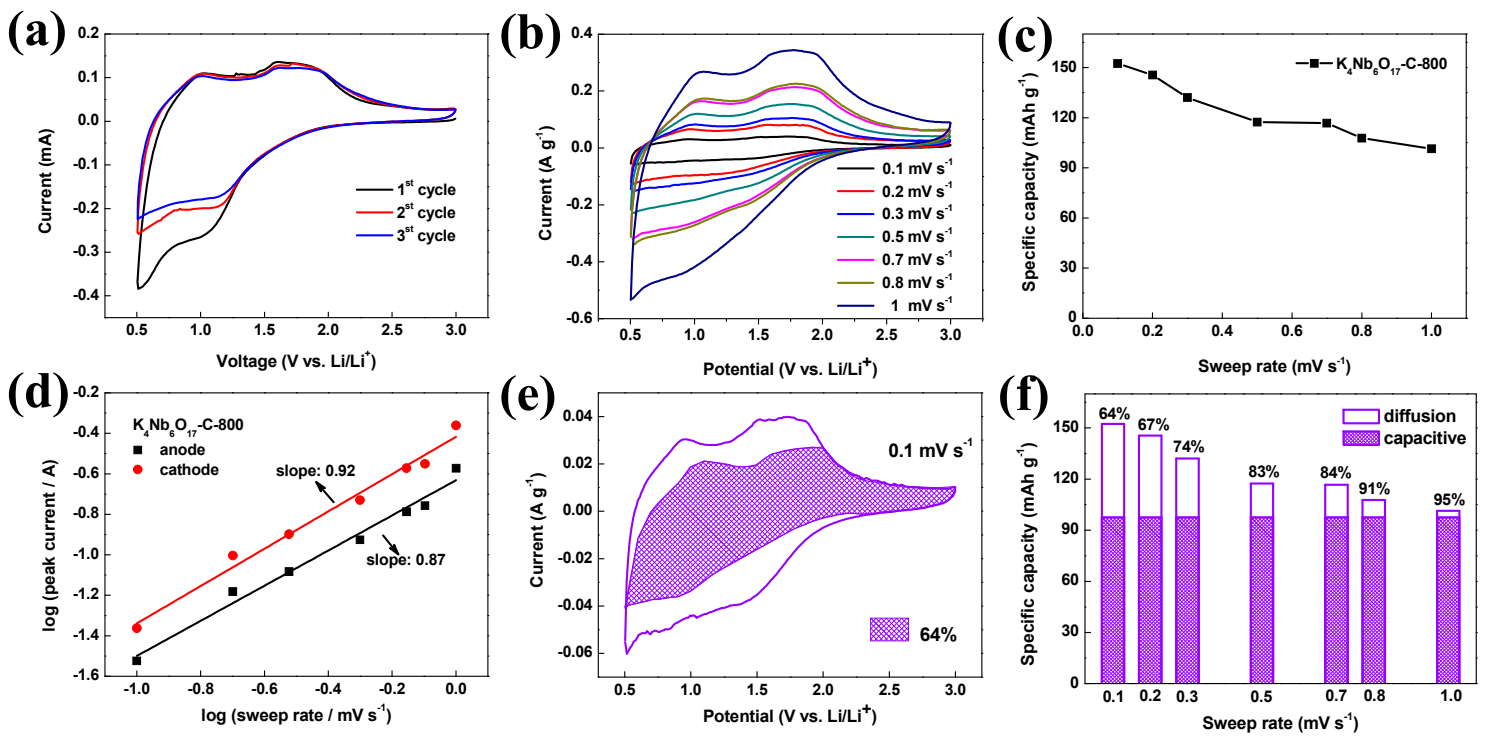

Figure 5. (a) The first three consecutive cyclic voltammetry (CVs) of the $\mathrm{K}_{4} \mathrm{Nb}_{6} \mathrm{O}_{17}-\mathrm{C}-800$ at a scan rate of $0.5 \mathrm{mV} \mathrm{s}^{-1}$. (b) The $\mathrm{CV}$ curves of $\mathrm{K}_{4} \mathrm{Nb}_{6} \mathrm{O}_{17}-\mathrm{C}-800$. (c) Plotting of capacitance versus sweep rate.

(d) Determination of the $b$ value of anode and cathode peak currents. (e) Total current (solid line) and capacitive current (shade region) at $0.1 \mathrm{mV} \mathrm{s}^{-1}$. (f) The capacitive contribution of $\mathrm{K}_{4} \mathrm{Nb}_{6} \mathrm{O}_{17}-\mathrm{C}-800$.

Figure 6 showed the discharge-charge curves for the selected cycles at a current density of 0.1 and $1 \mathrm{~A} \mathrm{~g}^{-1}$ with a cut off potential window of $0.5-3.0 \mathrm{~V}$, in which the voltage plateaus are in good agreement with the peaks of the CV curves in Figure 5a, even after extralong cycling. These outstanding electrochemical properties of $\mathrm{K}_{4} \mathrm{Nb}_{6} \mathrm{O}_{17}-\mathrm{C}-800$ were further emphasized by rate capability tests in Figure $7 \mathrm{a}$, the specific capacitance of $\mathrm{K}_{4} \mathrm{Nb}_{6} \mathrm{O}_{17}-\mathrm{C}-800$ in the first discharge process obtain $382 \mathrm{~mA} \mathrm{~h}$ $\mathrm{g}^{-1}$. With the increase of current densities from 0.05 to $5 \mathrm{~A} \mathrm{~g}^{-1}$, the charge/discharge capacities of all the cells declined because of cell polarization. The drastic drop in capacity is often associated with inevitable irreversible loss of lithium ions for the formation of the solid electrolyte interface layer (SEI). Unlike in many other battery chemistries, such as the $\mathrm{LiFePO}_{4}$, where extra lithium is provided for in the electrode to compensate for amount of lithium used for the SEI layer formation, the $\mathrm{K}_{4} \mathrm{Nb}_{6} \mathrm{O}_{17}-\mathrm{C}$ electrode do not have that extra $\mathrm{Li}+$ for this purpose [20,26-29]. The possible mechanisms of lithium ion intercalation:

$$
\begin{gathered}
\mathrm{Nb}^{5+}+\mathrm{e}^{-} \rightarrow \mathrm{Nb}^{4+} \\
\mathrm{K}_{4} \mathrm{Nb}_{6} \mathrm{O}_{17}+\mathrm{Li}^{+}+\mathrm{e}^{-} \rightarrow \mathrm{LiK}_{4} \mathrm{Nb}_{6} \mathrm{O}_{17} \\
\mathrm{C}+\mathrm{xLi}^{+}+\mathrm{xe}^{-} \rightarrow \mathrm{Li}_{\mathrm{x}} \mathrm{C}
\end{gathered}
$$
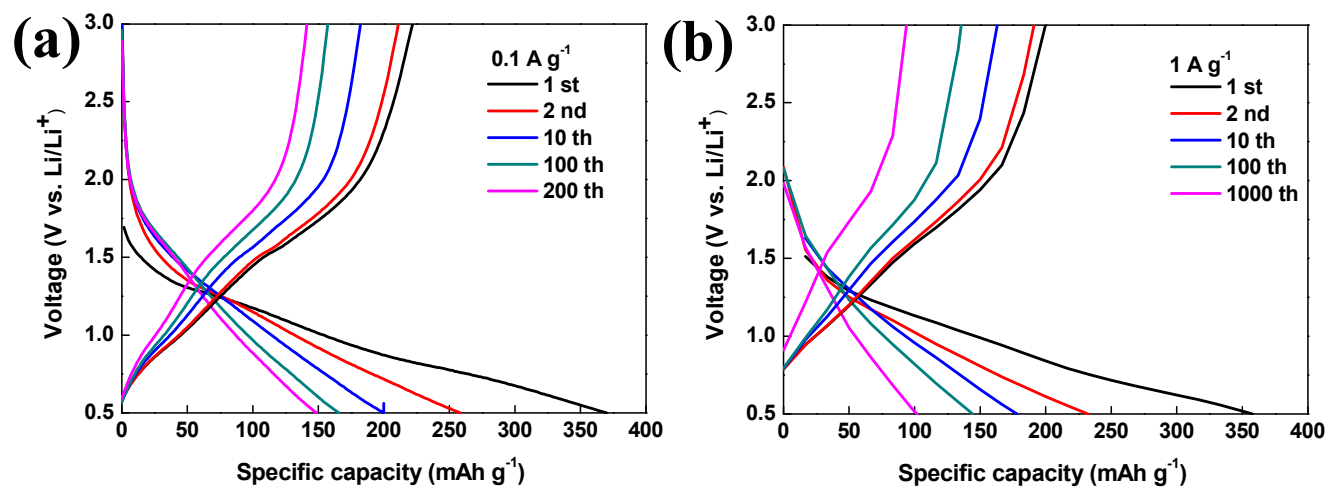

Figure 6. The charge/discharge profile of $\mathrm{K}_{4} \mathrm{Nb}_{6} \mathrm{O}_{17}-\mathrm{C}-800$ with the current density of (a) 0.1 and (b) $1 \mathrm{~A} \mathrm{~g}^{-1}$ at ambient temperature. 

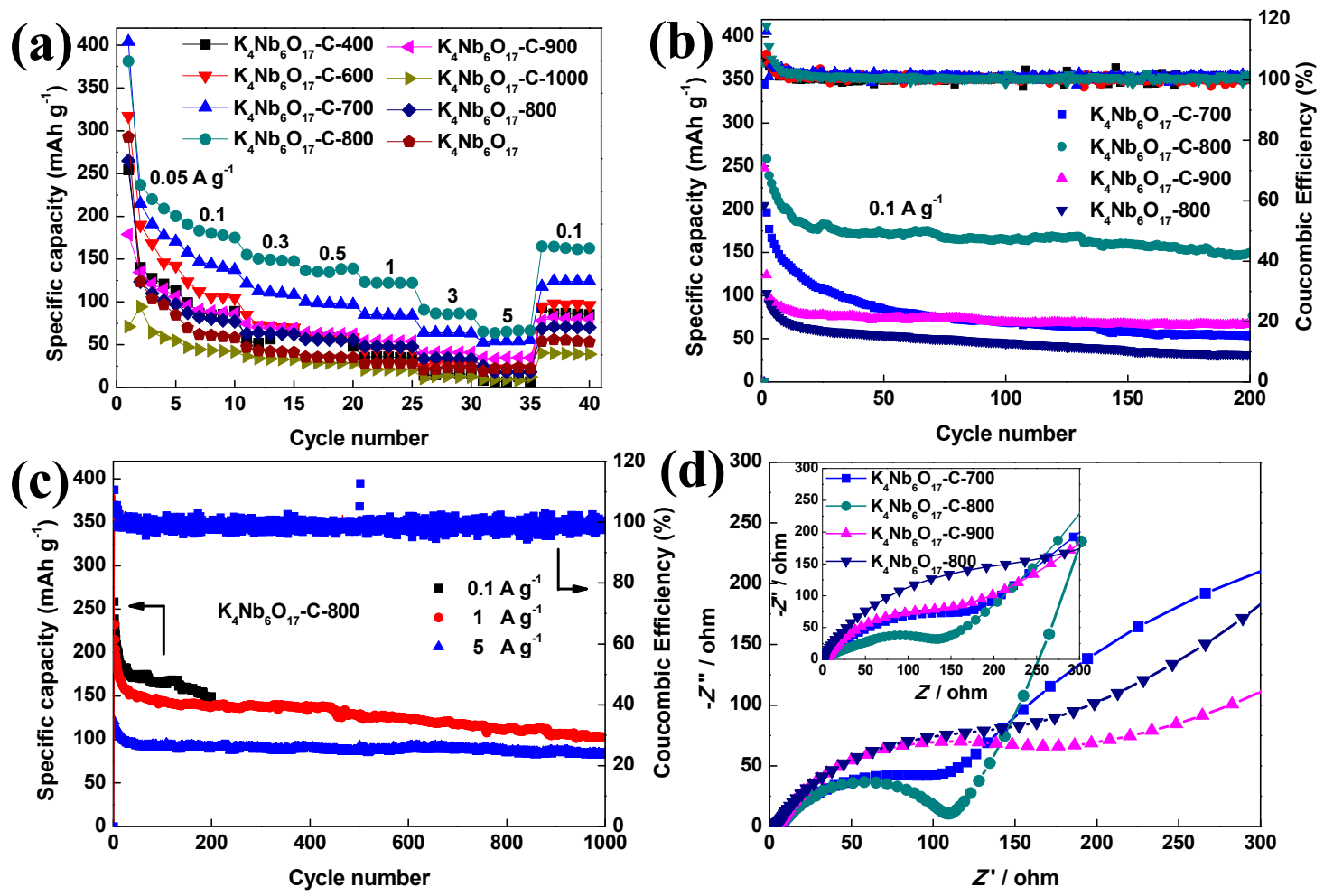

Figure 7. (a) Comparison of the capacities in dependence of cycle number of $\mathrm{K}_{4} \mathrm{Nb}_{6} \mathrm{O}_{17}-\mathrm{C}-800$ half-cells at various current densities from 0.05 to $5 \mathrm{~A} \mathrm{~g}^{-1}$. (b) The cycling stability of samples at a current density of $0.1 \mathrm{~A} \mathrm{~g}^{-1}$. (c) The cycling stability of $\mathrm{K}_{4} \mathrm{Nb}_{6} \mathrm{O}_{17}-\mathrm{C}-800$ at a current density of $0.1,1$, and $5 \mathrm{~A} \mathrm{~g}^{-1}$. (d) Nyquist plots of half-cell of the synthesis of $\mathrm{K}_{4} \mathrm{Nb}_{6} \mathrm{O}_{17}-\mathrm{C}$ nanosheet. The inset shows that the Nyquist plots of $\mathrm{K}_{4} \mathrm{Nb}_{6} \mathrm{O}_{17}-\mathrm{C}$ sample after 200 cycles with a current density of $0.1 \mathrm{~A} \mathrm{~g}^{-1}$.

The cell using $\mathrm{K}_{4} \mathrm{Nb}_{6} \mathrm{O}_{17}-\mathrm{C}-800$ nanosheets displayed the highest discharge capacities at all current densities, after undergoing a high current density of $5 \mathrm{~A} \mathrm{~g}^{-1}\left(67 \mathrm{~mA} \mathrm{~h} \mathrm{~g}^{-1}\right)$, a special capacity of $186 \mathrm{~mA} \mathrm{~h} \mathrm{~g}^{-1}$ can be sustained, while the current density returns to $0.1 \mathrm{~A} \mathrm{~g}^{-1}$ again, which indicates excellent reversibility and cycling stability of the $\mathrm{K}_{4} \mathrm{Nb}_{6} \mathrm{O}_{17}-\mathrm{C}-800$ nanosheets. As shown in Figure $7 \mathrm{~b}$, $\mathrm{K}_{4} \mathrm{Nb}_{6} \mathrm{O}_{17}-\mathrm{C}-800$ exhibited high reversible capacities of $102 \mathrm{~mA} \mathrm{~h} \mathrm{~g}^{-1}$ and $85 \mathrm{~mA} \mathrm{~h} \mathrm{~g}^{-1}$ undergoing 1000 cycles at $1 \mathrm{~A} \mathrm{~g} \mathrm{~g}^{-1}$ and $5 \mathrm{~A} \mathrm{~g}^{-1}$, respectively. The improvement can be attributed to the increase of conductivity and electron transfer property due to the introduction of carbon coating.

To understand the cycle retention characteristics, Figure $7 \mathrm{c}$ gives the cycling test that was conducted at $0.1 \mathrm{~A} \mathrm{~g}^{-1}$. Despite that some capacity decreased after 200 cycles, the $\mathrm{K}_{4} \mathrm{Nb}_{6} \mathrm{O}_{17}-\mathrm{C}-800$ electrode still preserved a discharge capacity of approximate $150 \mathrm{~mA} \mathrm{~h} \mathrm{~g}^{-1}$, correspond approximately $84 \%$ of the 20 th cycle $\left(201 \mathrm{~mA} \mathrm{~h} \mathrm{~g}^{-1}\right)$, and the coulombic efficiency was excellent $(100.6 \%)$. It should be emphasized that the specific capacity of $\mathrm{K}_{4} \mathrm{Nb}_{6} \mathrm{O}_{17}-\mathrm{C}-800$ was also superior to those of many reported $\mathrm{Nb}_{2} \mathrm{O}_{5}$ nanomaterials (see comparison in Table 1). Semicircle areas in the Nyquist plots at different frequencies refer to different aspects of electrochemical. Semicircle at high frequency represents the contact resistance, and that at medium frequency represents the charge transfer resistance. The straight line at low frequency represents the mass transfer of Li-ions [26]. As shown in Figure 7d, obviously, the diameter of the semicircle for $\mathrm{K}_{4} \mathrm{Nb}_{6} \mathrm{O}_{17}-\mathrm{C}-800$ was the smallest when compared with other samples, which demonstrates that $\mathrm{K}_{4} \mathrm{Nb}_{6} \mathrm{O}_{17}-\mathrm{C}-800$ owns the lower contact and charge transfer resistances, due to the increased conductivity of carbon doping. In the other hand, obviously, the diameter of the semicircle increases after 200 cycles with a current density of $0.1 \mathrm{~A} \mathrm{~g}^{-1}$, as compared with fresh uncycled cells, which demonstrates that $\mathrm{K}_{4} \mathrm{Nb}_{6} \mathrm{O}_{17}-\mathrm{C}$ possesses the lower contact and charge transfer resistances at the original state. The increase in resistance at the electrode/electrolyte interface for $\mathrm{K}_{4} \mathrm{Nb}_{6} \mathrm{O}_{17}-\mathrm{C}$ anode affected the lithium ion kinetics, which is correlated with the steady loss in the 
cell capacity during the initial cycles and continued to the 200th cycle. Due to the outstanding 2D structure and large specific surface, which afforded the short transport route for ion and electron and provided a large number of active sites for Li ion storage and shorter lithium ion transfer distance. All of these attributes contributed immensely to the improved cycling and performance of the $\mathrm{K}_{4} \mathrm{Nb}_{6} \mathrm{O}_{17}-\mathrm{C}$ composite electrode produced.

Table 1. A comparison study of performances between this work and the other related reports.

\begin{tabular}{|c|c|c|}
\hline Composites & Rate Capability & Cycling Stability \\
\hline $\mathrm{T}-\mathrm{Nb}_{2} \mathrm{O}_{5} / \mathrm{NS}-\mathrm{G}[30]$ & $\begin{array}{c}168 \mathrm{~mA} \mathrm{~h} \mathrm{~g}^{-1}\left(0.05 \mathrm{~A} \mathrm{~g}^{-1}\right) \\
106 \mathrm{~mA} \mathrm{~h} \mathrm{~g}^{-1}\left(5 \mathrm{~A} \mathrm{~g}^{-1}\right)\end{array}$ & 50 cycles $\sim 93.4 \%\left(0.1 \mathrm{~A} \mathrm{~g}^{-1}\right)$ \\
\hline $\mathrm{T}-\mathrm{Nb}_{2} \mathrm{O}_{5} @ \mathrm{C}[31]$ & $\begin{array}{c}188 \mathrm{~mA} \mathrm{~h} \mathrm{~g}^{-1}\left(0.1 \mathrm{~A} \mathrm{~g}^{-1}\right) \\
58 \mathrm{~mA} \mathrm{~h} \mathrm{~g}^{-1}\left(5 \mathrm{~A} \mathrm{~g}^{-1}\right)\end{array}$ & 1000 cycles $\sim 82.2 \%\left(0.1 \mathrm{~A} \mathrm{~g}^{-1}\right)$ \\
\hline $\mathrm{Nb}_{2} \mathrm{O}_{5} /$ carbon $[32]$ & $\begin{array}{c}170 \mathrm{~mA} \mathrm{~h} \mathrm{~g}^{-1}\left(0.05 \mathrm{~A} \mathrm{~g}^{-1}\right) \\
110 \mathrm{~mA} \mathrm{~h} \mathrm{~g}^{-1}\left(5 \mathrm{~A} \mathrm{~g}^{-1}\right)\end{array}$ & 4000 cycles $\sim 80 \%\left(5 \mathrm{~A} \mathrm{~g}^{-1}\right)$ \\
\hline Porous $\mathrm{Nb}_{2} \mathrm{O}_{5}[33]$ & $\begin{array}{c}159 \mathrm{~mA} \mathrm{~h} \mathrm{~g}^{-1}\left(0.2 \mathrm{Ag} \mathrm{g}^{-1}\right) \\
130 \mathrm{~mA} \mathrm{~h} \mathrm{~g}^{-1}\left(1 \mathrm{Ag}^{-1}\right)\end{array}$ & 150 cycles $~ 94 \%\left(0.5 \mathrm{~A} \mathrm{~g}^{-1}\right)$ \\
\hline $\mathrm{H}-\mathrm{Nb}_{2} \mathrm{O}_{5}$ microspheres [34] & $\begin{array}{l}161 \mathrm{~mA} \mathrm{~h} \mathrm{~g}^{-1}(1 \mathrm{C}) \\
109 \mathrm{~mA} \mathrm{~h} \mathrm{~g}^{-1}(5 \mathrm{C})\end{array}$ & 500 cycles $\sim 85 \%$ (5 C) \\
\hline $\mathrm{K}_{4} \mathrm{Nb}_{6} \mathrm{O}_{17}-\mathrm{NL}[20]$ & $\begin{array}{c}145 \mathrm{~mA} \mathrm{~h} \mathrm{~g}^{-1}\left(0.05 \mathrm{~A} \mathrm{~g}^{-1}\right) \\
81 \mathrm{~mA} \mathrm{~h}^{-1}\left(1 \mathrm{~A} \mathrm{~g}^{-1}\right)\end{array}$ & 200 cycles $\sim 86 \%\left(0.2 \mathrm{~A} \mathrm{~g}^{-1}\right)$ \\
\hline Our work & $\begin{array}{c}381 \mathrm{~mA} \mathrm{~h} \mathrm{~g}^{-1}\left(0.05 \mathrm{~A} \mathrm{~g}^{-1}\right) \\
133 \mathrm{~mA} \mathrm{~h} \mathrm{~g}^{-1}\left(\mathrm{~A} \mathrm{~g}^{-1}\right) \\
67 \mathrm{~mA} \mathrm{~h} \mathrm{~g}^{-1}\left(5 \mathrm{~A} \mathrm{~g}^{-1}\right)\end{array}$ & $\begin{array}{l}200 \text { cycles } \sim 84 \%\left(0.1 \mathrm{~A} \mathrm{~g}^{-1}\right) \\
1000 \text { cycles } \sim 64 \%\left(1 \mathrm{~A} \mathrm{~g}^{-1}\right) \\
1000 \text { cycles } \sim 84 \%\left(5 \mathrm{~A} \mathrm{~g}^{-1}\right)\end{array}$ \\
\hline
\end{tabular}

\section{Conclusions}

We have reported a facile design and synthesis of the strongly coupled $\mathrm{K}_{4} \mathrm{Nb}_{6} \mathrm{O}_{17}-\mathrm{C}$ nanosheets by one-step exfoliating and dopamine polymerization for carbonizing. Benefiting from the unique structural characteristic, the synthesizing hybrid nanosheets exhibited excellent performance in LIBs. Moreover, the electrode material showed pronounced capacities and stability at high current density. The facile procedure for the synthesis of the $\mathrm{K}_{4} \mathrm{Nb}_{6} \mathrm{O}_{17}-\mathrm{C}$ nanosheets, together with its prominent electrochemical performance, may motivate the exploration of more $2 \mathrm{D}$ nanostructured carbon doped metal oxide hybrid materials for energy storage related applications.

Author Contributions: H.L., Y.Z. and L.L. conceived and designed the experiments; X.W. and C.K. performed the experiments; all authors analyzed the data; H.L. wrote the paper; all authors discussed the results and commented on the paper.

Funding: This work was supported by the National Natural Science Foundation of China (No. 51503079), the Programs for Science and Technology of Zhejiang (No. 2017C31071 and 2018C37075) and the Program of Science and Technology Bureau of Jiaxing (No. 2016AY13008).

Conflicts of Interest: We declare that we have no conflict of interest.

\section{References}

1. Fairley, P. Energy storage: Power revolution. Nature 2015, 526, 102-104. [CrossRef] [PubMed]

2. Xiao, H.; Wang, S.; Zhang, S.; Wang, Y.; Xu, Q.; Hu, W.; Zhou, Y.; Wang, Z.; An, C.; Zhang, J. Interlayer expanded molybdenum disulfide nanosheets assembly for electrochemical supercapacitor with enhanced performance. Mater. Chem. Phys. 2017, 192, 100-107. [CrossRef]

3. Chu, S.; Majumdar, A. Opportunities and challenges for a sustainable energy future. Nature 2012, 488, 294-303. [CrossRef] [PubMed]

4. Pandolfo, A.; Hollenkamp, A.F. Carbon properties and their role in supercapacitors. J. Power Sources 2006, 157, 11-27. [CrossRef] 
5. Chao, D.; Xia, X.; Liu, J.; Fan, Z.; Ng, C.; Lin, J.; Zhang, H.; Shen, Z.; Fan, H. A V $2 \mathrm{O}_{5}$ /conductive-polymer core/shell nanobelt array on three-dimensional graphite foam: A high-rate, ultrastable, and freestanding cathode for lithium-ion batteries. Adv. Mater. 2014, 26, 5794-5800. [CrossRef] [PubMed]

6. Yu, Y.; Zhai, Y.; Liu, H.; Li, L. Single-layer $\mathrm{MnO}_{2}$ nanosheets: From controllable synthesis to free-standing film for flexible supercapacitors. Mater. Lett. 2016, 176, 33-37. [CrossRef]

7. Achour, A.; Lucio-Porto, R.; Chaker, M.; Arman, A.; Ahmadpourian, A.; Soussou, M.A.; Boujtita, M.; Brizoual, L.L.; Djouadi, M.A.; Brousse, T. Titanium vanadium nitride electrode for micro-supercapacitors. Electrochem. Commun. 2017, 77, 40-43. [CrossRef]

8. Liu, Z.; Zeng, Y.; Tang, Q.; Hu, A.; Xiao, K.; Zhang, S.; Deng, W.; Fan, B.; Zhu, Y.; Chen, X. Potassium vapor assisted preparation of highly graphitized hierarchical porous carbon for high rate performance supercapacitors. J. Power Sources 2017, 361, 70-79. [CrossRef]

9. He, Y.; Muhetaer, A.; Li, J.; Wang, F.; Liu, C.; Li, Q.; Xu, D. Ultrathin $\mathrm{Li}_{4} \mathrm{Ti}_{5} \mathrm{O}_{12}$ Nanosheet based hierarchical microspheres for high-rate and long-cycle life Li-ion batteries. Adv. Energy Mater. 2017, 7, 1700950. [CrossRef]

10. Zhang, J.; Wang, J.; Shi, Z.; Xu, Z. Mesoporous carbon material as cathode for high performance lithium-ion capacitor. Chin. Chem. Lett. 2018, 29, 620-623. [CrossRef]

11. Padashbarmchi, Z.; Hamidian, A.; Noonan, O.; Khorasani, N.; Kazemzad, M. A simple approach to prepare metal oxides supra-structures for LIBs. J. New Mater. Electrochem. Syst. 2015, 18, 87-90. [CrossRef]

12. Sun, Y.; Li, G.; Lai, Y.; Zeng, D.; Cheng, H. High rate lithium-sulfur battery enabled by sandwiched single ion conducting polymer electrolyte. Sci. Rep. 2016, 6, 22048. [CrossRef] [PubMed]

13. Wei, M.; Wei, K.; Ichihara, M.; Zhou, H. NbO nanobelts: A lithium intercalation host with large capacity and high rate capability. Electrochem. Commun. 2008, 10, 980-983. [CrossRef]

14. Jose, R.; Thavasi, V.; Ramakrishna, S. Metal oxides for dye-sensitive solar cells. J. Am. Ceram. Soc. 2009, 92, 289-301. [CrossRef]

15. Liu, X.; Que, W.; Xing, Y.; Yang, Y.; Yin, X.; Shao, J. New architecture of a petal-shaped NbO nanosheet film on FTO glass for high photocatalytic activity. RSC Adv. 2016, 6, 9581-9588. [CrossRef]

16. Kong, L.; Zhang, C.; Wang, J.; Qiao, W.; Ling, L.; Long, D. Free-Standing T- $\mathrm{Nb}_{2} \mathrm{O}_{5} /$ Graphene Composite Papers with Ultrahigh Gravimetric/Volumetric Capacitance for Li-Ion Intercalation Pseudocapacitor. ACS Nano 2017, 9, 11200-11208. [CrossRef]

17. Sun, H.; Mei, L.; Liang, J.; Zhao, Z.; Lee, C.; Fei, H.; Ding, M.; Lau, J.; Li, M.; Wang, C.; et al. Three-dimensional holey-graphene/ niobia composite architectures for ultrahigh-rate energy storage. Science 2017, 356, 599-604. [CrossRef]

18. Kudo, A.; Sayama, K.; Tanaka, A.; Asakura, K.; Domen, K.; Maruya, K.; Onishi, T. Nickel-Loaded $\mathrm{K}_{4} \mathrm{Nb}_{6} \mathrm{O}_{17}$ Photocatalyst in the Decomposition of $\mathrm{H}_{2} \mathrm{O}$ into $\mathrm{H}_{2}$ and $\mathrm{O}_{2}$ : Structure and Reaction Mechanism. J. Catal. 1989, 120, 337-352. [CrossRef]

19. Zhou, C.; Zhao, Y.; Shang, L.; Shi, R.; Wu, L.; Tung, C.-H.; Zhang, T. Facile synthesis of ultrathin $\mathrm{SnNb}_{2} \mathrm{O}_{6}$ nanosheets towards improved visible-light photocatalytic $\mathrm{H}_{2}$-production activity. Chem. Commun. 2016, 52, 8239-8242. [CrossRef] [PubMed]

20. Deng, Q.; Li, M.; Wang, J.; Zhang, P.; Jiang, K.; Zhang, J.; Hu, Z.; Chu, J. Boosted adsorption-photocatalytic activities and potential lithium intercalation applications of layered potassium hexaniobate nano-family. RSC Adv. 2017, 7, 28105-28113. [CrossRef]

21. Kestigian, M.; Leipziger, F.; Carter, J.R.; Garabedian, F.G. Preparation of $\mathrm{K}_{4} \mathrm{Nb}_{6} \mathrm{O}_{17}$ Single Crystals. J. Am. Ceram. Soc. 2010, 49, 517. [CrossRef]

22. Miyamoto, N.; Yamamoto, H.; Kaito, R.; Kuroda, K. Formation of extraordinarily large nanosheets from $\mathrm{K}_{4} \mathrm{Nb}_{6} \mathrm{O}_{17}$ crystals. Chem. Commun. 2002, 20, 2378-2379. [CrossRef]

23. Lim, E.; Jo, C.; Kim, H.; Kim, M.H.; Mun, Y.; Chun, J.; Ye, Y.; Hwang, J.; Ha, K.S.; Roh, K.C. Facile synthesis of $\mathrm{Nb}_{2} \mathrm{O}_{5} @$ Carbon core-shell nanocrystals with controlled crystalline structure for high-power anodes in hybrid supercapacitors. ACS Nano 2015, 9, 7497-7505. [CrossRef] [PubMed]

24. Lübke, M.; Sumboja, A.; Johnson, I.D.; Dan, J.L.B.; Shearing, P.R.; Liu, Z.; Darr, J.A. High power nano- $\mathrm{Nb}_{2} \mathrm{O}_{5}$ negative electrodes for lithium-ion batteries. Electrochim. Acta 2016, 192, 363-369.

25. Wang, J.; Polleux, J.; Lim, J.; Dunn, B. Pseudocapacitive contributions to electrochemical energy storage in $\mathrm{TiO}_{2}$ (anatase) nanoparticles. J. Phys. Chem. C 2007, 111, 14925-14931. [CrossRef] 
26. Agubra, V.A.; Zuniga, L.; de la Garza, D.; Gallegos, L.; Pokhrel, M.; Alcoutlabi, M. Forcespinning: A new method for the mass production of $\mathrm{Sn} / \mathrm{C}$ composite nanofiber anodes for lithium ion batteries. Solid State Ion. 2016, 286, 72-82. [CrossRef]

27. Agubra, V.A.; Zuniga, L.; de la Garza, D.; Gallegos, L.; Pokhrel, M.; Alcoutlabi, M. A comparative study on the performance of binary $\mathrm{SnO}_{2} / \mathrm{NiO} / \mathrm{C}$ and $\mathrm{Sn} / \mathrm{C}$ composite nanofibers as alternative anode materials for lithium ion batteries. Electrochim. Acta 2017, 224, 608-621. [CrossRef]

28. Huang, X.D.; Zhang, F.; Gan, X.F.; Huang, Q.A.; Yang, J.Z.; Lai, P.T.; Tang, W.M. Electrochemical characteristics of amorphous silicon carbide film as a lithium-ion battery anode. RSC Adv. 2018, 8, 5189-5196. [CrossRef]

29. Cheong, J.Y.; Kim, C.; Jung, J.W.; Yoon, K.R.; Cho, S.H.; Youn, D.Y.; Jang, H.; Kim, I.D. Formation of a surficial bifunctional nanolayer on $\mathrm{Nb}_{2} \mathrm{O}_{5}$ for ultrastable electrodes for lithium-ion battery. Small 2017, 13, 1603610. [CrossRef]

30. Jiao, X.; Hao, Q.; Liu, P.; Xia, X.; Wu, L.; Liu, X. Facile synthesis of $\mathrm{T}-\mathrm{Nb}_{2} \mathrm{O}_{5}$ nanosheets/nitrogen and sulfur co-doped graphene for high performance lithium-ion hybrid supercapacitors. Sci. Chin. Mater. 2018, 61, 273-284. [CrossRef]

31. Yang, H.; Xu, H.; Wang, L.; Zhang, L.; Huang, Y.; Hu, X. Microwave-assisted rapid synthesis of self-Assembled $T-\mathrm{Nb}_{2} \mathrm{O}_{5}$ nanowires for high-energy hybrid supercapacitors. Chem. Eur. J. 2017, 23, 4203-4209. [CrossRef]

32. Lim, E.; Kim, H.; Jo, C.; Chun, J.; Ku, K.; Kim, S.; Lee, H.; Nam, I.; Yoon, S.; Kang, K. Advanced hybrid supercapacitor based on a mesoporous niobium pentoxide/carbon as high-performance anode. ACS Nano 2014, 8, 8968-8978. [CrossRef] [PubMed]

33. Liu, G.; Jin, B.; Bao, K.; Xie, H.; Guo, J.; Ji, X.; Zhang, R.; Jiang, Q. Facile synthesis of porous $\mathrm{Nb}_{2} \mathrm{O}_{5}$ microspheres as anodes for lithium-ion batteries. Int. J. Hydrog. Energy 2016, 42, 6065-6071. [CrossRef]

34. Liu, X.; Liu, G.; Liu, Y.; Sun, R.; Ma, J.; Guo, J.; Hu, M. Urchin-like hierarchical $H-\mathrm{Nb}_{2} \mathrm{O}_{5}$ microspheres: Synthesis, formation mechanism and their applications in lithium ion batteries. Dalton Trans. 2017, 46, 10935-10940. [CrossRef] [PubMed] 